\title{
THE SPECIFICITY OF LITERARY PROPER NAMES: HARRY POTTER IN TRANSLATION INTO POLISH AND RUSSIAN
}

\section{Introductory remarks}

A literary text is constructed on the basis of the literary setting the boundaries of which are set by proper names, whereby these proper names are filled with content based on a literary text. Although the readers always deal with literature in a material - textual - form, all processes of visualisation of the literary world occur within their minds. This is because the process of creating and reading of a literary text is utterly discursive by nature. Accordingly, in the paper discourse is understood as the totality of verbal and mental activity that underlies all human actions, including interacting with texts. ${ }^{1}$ In other words, a literary text is only a material form that allows, on the one hand, the writer to express his or her image of the literary setting and, on the other hand, the reader to recreate this setting in his or her mind. In both cases, the setting consists of particular elements that become fused with their respective names. It means that a literary text and its proper names are interdependent entities, since one cannot exist without the other. Irrespective of how obvious this tight link may seem, the nature of literature entails highly problematic issues of semantics of their names as well as of ontology of literary characters.

* Konrad Rachut - magister, doktorant w Instytucie Filologii Rosyjskiej i Ukraińskiej na Wydziale Neofilologii Uniwersytetu im. Adama Mickiewicza w Poznaniu; obszar badań: tworzenie, odbiór i tłumaczenie literackich nazw własnych; zainteresowania naukowe: komunikacja niewerbalna w tłumaczeniu symultanicznym, teoria tekstu literackiego; kontakt: e-mail: konrad.rachut@gmail.com.

1 Николай Ф. Алефиренко, „Имплицитность художественного слова как когнитивно-дискурсивная категория", Научные ведомости Белгородского государственного университета. Серия: Гуманитарные науки 10 (2011), 12: 5. 
As the process of literary communication is discursive - therefore highly personalised - the situation becomes even more complex in the case of literary translation. An original text is always deeply rooted in its respective language and culture, so the sufficient recreation of its verbal layer and underlying mental space poses a challenge for its translator. It can be assumed that he or she should focus on retaining the correspondence between chosen properties of the signifieds and their onymic labels, since a literary world consists of highly developed elements that are explicitly or implicitly "summed up" by their names. Interestingly enough, translation is a process of decision-making that requires the individual to select a translational strategy - either way, regardless of which strategy he or she resorts to, it always results in obliteration of some aspects of semantics of literary proper names as well as of the ontological status of fictional characters. This is the focus of the analysis of Polish and Russian translations of the Harry Potter series - it is based on the excerpts from the texts in relation to the proper names of chosen elements of J.K. Rowling's magical universe. It is worth mentioning that this particular issue was also addressed in the works of Gibka $^{23}$, Kudlik ${ }^{4}$ and Małek ${ }^{5}$.

\section{Semantics of literary proper names}

As Newmark admits, the function of literary proper names is both to "name" and to "mean" particular information about its bearer that is important for the writer. ${ }^{6}$ In fact, Tynyanov expands this postulate even further, acknowledging that all literary proper names are "telling", because the writer purposefully uses them in order to develop their semantical potential by means of a text. ${ }^{7}$

In this context it should be purported that, from the perspective of the literary setting, the text itself

2 Martyna Gibka, „Hooch, Filch i Puszek, czyli jak polskie tłumaczenie Harry’ego Pottera wpływa na funkcję humorystyczną nazw własnych postaci”, in: Emocje w językach i kulturach świata, eds. E. Komorowska, A. Szlachta (Szczecin: Volumina.pl Daniel Krzanowski, 2016).

3 Martyna Gibka, "Hooch, Filch and Fluffy: How the polish translation of Harry Potter influences the humorous function of the characters' names", in: Komunikacja międzykulturowa $w$ świetle wspótczesnej translatologii. Literatura, eds. E. Kujawska-Lis, I. Ndiaye (Olsztyn: UWM w Olsztynie, 2014).

4 Małgorzata Kudlik, "Переводческие практики в передаче смысловых имен собственных в польском и русском переводах книги Дж.К. Ролинг Гарри Поттер и философский камень”, in: Wschód-Zachód. Dialog kultur, ed. Z. Nowożenowa (Słupsk: Wydawnictwo Naukowe Akademii Pomorskiej, 2006).

5 Magdalena Małek, „O tłumaczeniach książki Harry Potter and the Deathly Hallows autorstwa J.K. Rowling”, in: Debiuty Naukowe II. Terminologia - translatoryka - terminografia, ed. M. Łukasik (Warszawa: Katedra Języków Specjalistycznych - Koło Naukowe BAJT, 2008).

6 Paul Newmark, Approaches to Translation (Oxford: Pergamon, 1981), 70.

7 Юрий Н. Тынянов, Поэтика. История литературы (Москва: Кино, 1977), 186-187. 
serves as the means whereby a quasi-indexical reference to the character can be made by means of which that very fictional object can be baptized by author or readers. Something counting as a baptismal ceremony can be performed by means of writing the words of the text or it can be merely recorded in the text, or (if the character is named later, for example by readers), it can remain unrecorded in the text. ${ }^{8}$

Accordingly, a "baptism" of the literary object is an integral part of the creative work of the writer. In fact, it is an indispensable stage of constructing the literary world as a whole, as it consists of distinguishable and clearly defined elements. The first appearance of either the proper name itself, or a description of its bearer that is absorbed by the name, can be therefore defined as the birth of the element of the setting. Thus, a direct correspondence between the form/content of the literary name itself and an object it refers to becomes evident. ${ }^{9}$

Although a name always foregrounds chosen properties of its bearer by means of antonomasia, it, in fact, carries the totality of its respective descriptions that are underpinned by cognitive, pragmatic and emotional background. Thus, a name serves as a tool of creating an illusion of the existence of its bearer, and an image of the bearer is triggered in the mind of readers every time they encounter his or her name. A literary name has a meaning specifically because it triggers an image of the element of the literary world by means of explicit linguistic or implicit cultural and discursive facts. This is why the process of interacting with literature can be defined as challenging in terms of the reader's knowledge and imaginative potential.

This may lead to an observation that ontology of the elements of a literary world and semantics of their respective names depend on each other. It means that its signified is "brought to life" by the writer as of the moment of the first appearance of a given name in the literary text. Consequently, each time the name reappears, it reawakes the mental representation of its signified in the mind of a reader that is constructed on the basis of his or her descriptions. Nonetheless, one cannot purport that the words through which the writer refers to their signified can be considered as its definition. It has been already pinpointed that the literary world is a mental entity. Bearing this in mind, one may realise that a text is only a mere point of reference for the reader that results in stimulating his or her discursive activity. It produces a mental construct representing the particular element of the setting - it should be named a concept. Yet, as determining the specificity of a literary concept resides beyond the scope of the paper, it will be sufficient to assume that the signified of a name is present not in the text, but in the mind of the reader.

8 Amie L. Thomasson, Fiction and Metaphysics (Cambridge: Cambridge UP, 1999), 47.

9 Yvonne Bertills, Beyond Identification. Proper names in children's literature (Åbo: Åbo Akademi University Press, 2003), 4. 
All the aforementioned remarks lead to the classification of literary proper names developed by Bertills that is different from the most traditional one, as the latter is based on the distinction between fictive and non-fictive names. According to the former classification, as Bertills asserts, all names in literature are indeed fictive. ${ }^{10}$ It can be attributed to the fact that even though a name may be adopted from the extralinguistic reality along with chosen characteristics of its real bearer, its signified in a literary text will be still a mental representation of the original one, therefore being inherently subjective and fragmentary.

Thus, fictive names can be divided into three groups, namely: conventional, invented and imaginary. ${ }^{11}$ In fact, Bertills distinguishes yet another group, that is semantically loaded names, however, as it has been already suggested, all literary proper names can be termed as semantically loaded. The problem comes down to the degree of the explicitness of the link between an idea and the name, so its decrypting is totally up to the insightfulness of the reader. As far as this classification is concerned, the first group includes proper names that are adapted from the non-literary reality. Because of this, they may carry the information connected with the individual who originally possessed the given name - the process of instilling this information in a literary name is called deonimisation. ${ }^{12}$ The second group involves names that are onymic neologisms being constructed from scratch by the writer. By means of this, he or she makes it highly representative of characteristic traits of the object endowed with the name, as the writer is focused specifically on matching the latter to the former. Lastly, the third group consists of names that have no apparent relation to neither the onomasticon, nor the lexicon of a given language. Ultimately, one can assert that a literary text is dependent on the will of its author, whereby its words (along with proper names) are designed to materialise particular literary concepts.

\section{Translation of literary proper names}

In the face of such a complex nature of proper names in single-language literary communication, one may question the possibility of translating them into different languages. Due to this, doubts may arise whether there are any strategies that can allow retaining the totality of the semantic and ontological specificity of literary proper names. As far as the first issue is concerned, leaving aside the obvious aspect of language and culture change, translation entails interpretation by nature. Ideally, the translator should enlist all the potential equivalents of a given linguistic unit as well as

10 Ibidem, 10-11.

11 Ibidem.

12 Mariusz Rutkowski, Nazwy własne w strukturze metafory i metonimii. Proces deonimizacji (Olsztyn: Wydawnictwo UWM, 2007), 29-30. 
reflect on the consequences that originate from selecting each variant. ${ }^{13}$ Nonetheless, as translation is always a re-creation of the original structure and content, it leads to narrowing it down. Hence, translation is possible, yet it will be always fragmentary.

When it comes to translational strategies, they are related to Venuti's distinction between "domestication" and "foreignisation". ${ }^{14}$ Accordingly, within the scope of domestication there are two strategies available, namely transposition and translation. ${ }^{15}$ Applying them equals imposing a partial interpretation of a denoted element of the literary world, as it forces the translator to focus on either formal or semantic aspects of the given proper name. It stems from the fact that transposition involves orthographical or grammatical adaptation of the source language proper name to the rules of the target language. Thus, by means of this, the translator does not render the meaning of the constituents of the proper name. As far as translation is concerned, it requires the translator to retain chosen semantic aspects of the proper name in question. This originates from the fact that the writer often takes advantage of the polysemic potential of common nouns out of which the name is constructed that is not usually present in the equivalents of the target language. Consequently, he or she is forced to decide which layer of the original polysemy is crucial for the general understanding of the signified as well as the entire literary work.

Conversely, foreignisation manifests itself through translocation, whereby the form of a proper name remains exactly as it was in the original text. ${ }^{16}$ On the one hand, it means no interference on the part of the translator that allows the reader to engage in the interpretation of the proper name. On the other hand, in the face of such a form of the proper name, the reader is incapable of understanding it unless he or she either knows the source language or embarks on the necessary linguistic analysis. Nonetheless, resorting to foreignisation allows for leaving the literary world intact, yet makes it look far more like the original text.

\section{An analysis of Harry Potter proper names in translation}

Having briefly considered the crucial problems regarding proper names in the source language text as well as their subsequent interpretation in translation, these observations should be verified on the basis of the material excerpted from the Harry Potter saga. The methodology of this analysis is grounded in confronting the names of a

13 Jiri Levy, „Przekład jako proces podejmowania decyzji”, in: Wspótczesne teorie przekładu. Antologia, eds. P. Bukowski, M. Heydel (Kraków: Znak, 2009), 73.

14 Lawrence Venuti, The Translator's Invisibility: A History of Translation (London \& New York: Routledge, 1995), 20.

15 Aleksandra Cieślikowa, „Jak „ocalić w tłumaczeniu” nazwy własne”, in: Między oryginałem a przekładem, t. II: Przekład, jego tworzenie się i wpływ (Kraków: Księgarnia Akademicka, 1996), 317.

16 Ibidem, 318. 
character, an animal and an object with their descriptions and determining whether the latter indeed realise the semantic potential of the former. At the outset, the investigation is conducted within the original text. Conclusions drawn from it are then projected onto the Polish and Russian equivalents of both proper names and chosen excerpts from the text in order to establish the degree to which the original and translational conglomerates reflect each other. Yet, it should be noted that with a view to making the analysis as in-depth as possible, the author of the paper have chosen one anthroponym (Harry Potter), one zoonym (Fluffy) and one chrematonym (The Mirror of Erised).

\section{Example 1}

English: Harry Potter. Polish: Harry Potter. Russian: Гарри Поттер.

The anthroponym Harry Potter belongs to the category of conventional proper names - both the first name and the surname of the character are taken from the nonliterary environment. In fact, both of them are the realisation of J.K. Rowling's preferences. This can be regarded as a way of expressing her emotional attitude towards the character, so Harry Potter himself can be treated as "her ghostly son". As J.K. Rowling admits, "'Harry' has always been my favourite boy's name, so if my daughter had been a son, he would have been Harry Rowling". ${ }^{17}$

Apart from this, the name Harry is a relatively common name in England - this is pinpointed explicitly in the text of the first volume of the series.

Excerpt 1

English version

'Harry. Nasty, common name, if you ask me.'

'Oh, yes,' said Mr Dursley, his heart sinking horribly. 'Yes, I quite agree.'18

Polish version

- Harry. Obrzydliwe, pospolite imię.

- Och, tak... - mruknął pan Dursley, a serce w nim zamarło. - Tak, zgadzam się z tobą całkowicie. $^{19}$

Russian version

- Гарри. Отвратное, простонародное имя!

- Да-да, - сказал мистер Дурслей. У него прямо-таки оборвалось сердце. - Абсолютно с тобой согласен. ${ }^{20}$

17 "About the Books: transcript of J.K. Rowling's live interview on Scholastic.com", access 02.05.2017, http://www.accio-quote.org/articles/2000/1000-scholastic-chat.htm.

18 Joanne K. Rowling, Harry Potter and the Philosopher's Stone (London: Bloomsbury, 2004), 11.

19 Joanne K. Rowling, Harry Potter i Kamień Filozoficzny (Poznań: Media Rodzina, 2000), 12.

20 Джоанн К. Роулинг, Гарри Поттер и Философский камень (Москва: Махаон, 2017), 16. 
The choice of this particular name can be therefore interpreted as a way of highlighting the fact that Harry is an ordinary boy with whom every reader can identify. He is often considered an everyman, but with an "icing on the cake", that is his outstanding magical abilities. J.K. Rowling admits this by saying that "He's every boy... but with a twist". ${ }^{21}$

As far as his surname is concerned, the word potter in English has two discrepant meanings. The primary one is that of a noun which stands for a person whose occupation revolves around making various ceramic wares. This semantic aspect of the surname can be approached metaphorically. Yet, when it comes to the secondary meaning of the word potter, being a verb that represents an action of wandering around or acting in a vague and unmotivated way, it realises itself quite literally in the deeds of the character.

The former meaning is depicted in character's decisions, and this is a metaphorical representation of the job of a potter - by means of his actions, he factually molds and shapes his fate as if it was a clay vessel.

Excerpt 2

English version

Harry then did something that was both very brave and very stupid: he took a great running jump and managed to fasten his arms around the troll's neck from behind. ${ }^{22}$

Polish version

Harry zrobił wówczas coś, co było bardzo odważne i bardzo głupie: rozpędził się i skoczył trollowi na plecy, oplatając ręce wokół jego szyi. ${ }^{23}$

Russian version

И тогда Гарри совершил поступок очень смелый и очень глупый: разбежался, подпрыгнул и повис у тролля на шее. ${ }^{24}$

Harry Potter was particularly stubborn in fighting with the main antagonist of the series, Lord Voldemort. Although he was deemed to have no chances of winning the battle, it was revealed in Harry Potter and the Order of the Phoenix that he was indeed "the chosen one" predestined to fight with the Dark Lord. ${ }^{25}$ Thus, being utterly innocent as he was, Harry turned out to be the leader of the good characters in the series. This somehow corresponds with the implicit connotation that the name Harry

21 BBC, Harry Potter and Me, access 02.05.2017, http://www.accio-quote.org/articles/2002/1102-aebiography.htm.

22 Rowling, Harry Potter and the Philosopher's, 130.

23 Rowling, Harry Potter i Kamień, 185.

24 Роулинг, Гарри Поттер и Философский, 248.

25 Joanne K. Rowling, Harry Potter and the Order of the Phoenix (London: Bloomsbury, 2003), 693. 
might trigger, as it is a short form of Henry - this was a name of many kings in the history of England.

Excerpt 3

English version

It's only dying a bit later than I would have done, because I'm never going over to the Dark Side! I'm going through that trapdoor tonight and nothing you two say is going to stop me! Voldemort killed my parents, remember? ${ }^{26}$

Polish version

Jeśli mnie złapią, zanim dostanę się do Kamienia, to trudno, wrócę do Dursleyów i będę czekał, aż Voldemort tam mnie dopadnie, po prostu umrę trochę później, bo nigdy, przenigdy nie stanę po stronie czarnej magii! Tej nocy wejdę tam i żadne $\mathrm{z}$ was mnie nie powstrzyma! Voldemort zabił moich rodziców, zapomnieliście o tym! ${ }^{27}$

\section{Russian version}

Если я попадусь, не добуду камень - ну, значит, отправляюсь назад к Дурслеям и буду ждать, пока до меня доберется Вольдеморт... Просто умру чуть позже, чем планировалось... Потому что я никогда не перейду к силам зла! Сегодня ночью я иду в хранилище, говорите что хотите, вы меня не остановите! Вольдеморт, между прочим, убил моих родителей! ${ }^{28}$

It can be therefore said that the meaning of the name Harry Potter is a combination of linguistic and extralinguistic knowledge. Possessing it may translate into appropriate understanding of the character and the relation between his personality and name. Nonetheless, primarily English people can be expected to be aware of this, while for Polish and Russian readers these facts might remain unnoticed.

Thus, as far as Polish and Russian translations are concerned, they take the following shape: Harry Potter and Гарри Поттер, respectively. The Polish translator, Andrzej Polkowski, decided to translocate the name of the protagonist of the series, therefore depriving it of all the meaning for Polish readers. However, he compiled a thesaurus of proper names and common nouns that were interesting from his point of view and put them at the end of each volume - he indeed devoted an entry to the main protagonist, yet deciphering only the meaning of his surname. ${ }^{29}$ In turn, the Russian translator, Maria Spivak, opted for transliteration in order to make the name more formally familiar to Russian readers, which is, in fact, in accordance with the Russian tradition of transliterating all foreign proper names. Nonetheless, it deters Russian readers from distilling the meaning of the name Harry Potter, which is hindered

26 Rowling, Harry Potter and the Philosopher's, 197.

27 Rowling, Harry Potter i Kamień, 279-280.

28 Роулинг, Гарри Поттер и Философский, 377-378.

29 Rowling, Harry Potter i Kamień, 323. 
even more by the fact that she did not use any strategy of explicating the information hidden in the name. Consequently, as can be seen in Excerpts 1, 2 and 3 above, the descriptions of the protagonist are carefully retained in Polish and Russian translations, however not projecting onto the name.

\section{Example 2}

English: Fluffy. Polish: Puszek. Russian: Пушок.

The zoonym Fluffy also originates from the non-literary world, belonging to the category of conventional names - it is used for naming pets. As such, it is relatively easy to understand the reason why it was used by J. K. Rowling, as it is based on the word fluff that is a synonym of fur. Taken out of the context of the series, the word fluffy is an adjective used to describe the softness of a material. However, for the purposes of the animal named Fluffy, J. K. Rowling proprialised the word. Although it may imply referring to a small, cute pet, it stands for a gigantic, three-headed monster-dog that guards the entrance to the location where the Philosopher's Stone was hidden. Thus, the name is primarily of ironic nature, since when the trio of protagonists of the saga (Harry Potter, Hermione Granger and Ron Weasley) encountered the dog for the first time,

\section{Excerpt 1}

\section{English version}

[t]hey were looking straight into the eyes of a monstrous dog, a dog which filled the whole space between ceiling and floor. It had three heads. Three pairs of rolling, mad eyes; three noses, twitching and quivering in their direction; three drooling mouths, saliva hanging in slippery ropes from yellowish fangs. ${ }^{30}$

\section{Polish version}

Patrzyli prosto w ślepia monstrualnego psa - psa, który wypełniał całą przestrzeń między sufitem a podłogą. Pies miał trzy głowy. Trzy pary wytrzeszczonych, wściekłych oczu, trzy nosy, dygocące i marszczące się w ich stronę, trzy potworne pyski o żółtych kłach, z których wisiały strąki śliny. ${ }^{31}$

\section{Russian version}

Они смотрели в глаза чудовищному псу - громадине от пола до потолка. И у пса было три головы. Три пары вытаращенных, бешеных глаз, три пары раздувшихся ноздрей, три разинутых пасти, и с пожелтевших клыков скользкими веревками свисали слюни. ${ }^{32}$ 
This creature should be interpreted as a reference to the mythical dog, Cerber, since the former reminds the latter not only in terms of its function (guarding an entrance to an important place), but also in terms of its looks. ${ }^{33}$ It should be noted that Hagrid, the forest ranger and Keeper of Keys and Grounds of Hogwarts, named the dog Fluffy. He was truly fascinated by such creatures, not perceiving any danger and monstrosity in them, thus approaching them with care and gentleness. This is the exact reason why such a monster was given such a sweet-sounding name.

Excerpt 2

English version

Hagrid dropped the teapot.

'How do you know about Fluffy?' he said.

'Fluffy?'

'Yeah - he's mine - bought him off a Greek chappie I met in the pub las' year - I lent him to Dumbledore to guard the - ${ }^{34}$

Polish version

Hagrid wypuścił z rąk dzbanek.

- Skąd wiecie o Puszku? - zapytał.

- O Puszku?

- No tak... to mój pies... kupiłem go od jednego Greka... w pubie, w zeszłym roku... pożyczyłem go Dumbledore'owi, żeby pilnował... ${ }^{35}$

Russian version

Огрид выронил чайник.

- Как вы узнали про Пушка?

- Пушка?

- Ну да... Это мой пес... Прикупил у одного грека, в пабе познакомились в том году... А сейчас одолжил Думбльдору сторожить... ${ }^{36}$

In this case, both Polkowski and Spivak opted for translation. They decided to mirror the formal structure of the original name by means of finding equivalents of the root fluff (Pusz and Пуш) and the suffix -y (-ek and -ок) - this is an instance of calquing the structure of the original name. As a result, they managed to preserve the meaning instilled within the name as well as to project the descriptions onto the name. It may be ascribed to the fact that the English Fluffy is not heavily semantically

33 Allan Z. Kronzek, Elizabeth Kronzek, Księga wiedzy czarodziejskiej. Przewodnik po zaczarowanym świecie Harry'ego Pottera (Poznań: Dom Wydawniczy Rebis), 253-254.

34 Rowling, Harry Potter and the Philosopher's, 141.

35 Rowling, Harry Potter i Kamien, 126.

36 Роулинг, Гарри Поттер и Философский, 271. 
loaded, so the meaning of the name is relatively explicit and no polysemy is present in it.

\section{Example 3}

English: The Mirror of Erised. Polish: Zwierciadto Ain Eingarp. Russian: Зеркало Джедан.

This chrematonym can be assigned to the group of invented literary proper names. It denotes a mirror that has highly magical properties - it reflects the deepest desires of a person who looks at it.

\section{Excerpt 1}

\section{English version}

It shows us nothing more or less than the deepest, most desperate desire of our hearts. ${ }^{37}$

Polish version

Pokazuje nam ni mniej, ni więcej, tylko najgłębsze, najbardziej utęsknione pragnienie naszego serca. ${ }^{38}$

Russian version

Оно показывает наши самые сокровенные желания. Не больше и не меньше. ${ }^{39}$

The property of the mirror is verbalised by means of the second part of its name, of Erised, yet being somehow hidden. It stems from the fact that the word desire is written backwards here. It can be interpreted as an attempt to make an impression that the mirror is an ancient artefact. In fact, the technique of writing in reverse direction is used for both the name of the mirror and the entire inscription above it:

It was a magnificent mirror, as high as the ceiling, with an ornate gold frame, standing on two clawed feet. There was an inscription carved around the top: Erised stra ehru oyt ube cafru oyt on wohsi. ${ }^{40}$

Putting the inscription in the natural order and changing the location of spaces between the words leads to forming the following sentence: I show not you face but your heart's desire. Apparently, by means of using this technique, J.K. Rowling wanted to make it look as if it was an old language, possibly extinct. Therefore, in the case of this proper name, it is vital to focus on not only its semantics, but also on its form.

As far as the translations are concerned, Polkowski decided to retain the structure the mirror of desire by means of using the possessive case and writing the word prag-

37 Rowling, Harry Potter and the Philosopher's, 157.

38 Rowling, Harry Potter i Kamień, 222.

39 Роулинг, Гарри Поттер и Философский, 300.

40 Rowling, Harry Potter and the Philosopher's, 152. 
nienia in reverse. Exactly as it is in the English text, the name of the mirror is located at the beginning of the inscription:

\section{Polish version}

Było to piękne lustro, oparte o ścianę, sięgające aż do sufitu, w bogato zdobionej złotej ramie. Na szczycie ramy widniał napis:

AIN EINGARP ACRESO GEWTEL AZ RAWTĄ WTE IN MAJ IBDO. ${ }^{41}$

The impression of it being an ancient mirror is recreated here through the part ain, which may resemble Latin or German. When put in the proper order, the inscription goes like this: Odbijam nie Twa twarz, ale Twego serca pragnienia - it is an accurate rendition of the source language one.

Spivak also opted for the strategy of writing the equivalent of the word desire (надежда) backwards. It is worth pinpointing that the Russian word is only a partial translation of the original word, as it rather stands for hope than desire. On the one hand, Spivak reflected the English structure of Erised, as she put the noun in the possessive case. On the other hand, she decided to pluralise it, although desire is singular in the original proper name. Apart from this, there is a significant deviation from the original in terms of the aforementioned inscription, since the Russian translator did not put the name of the mirror in its beginning - it is located in the middle, making the entire sentence lose its original specificity.

\section{Russian version}

Великолепное зеркало - до потолка, в резной золоченой раме, на двух когтистых лапах. Поверху резная надпись: «Иов тяин евор косон килен». ${ }^{42}$

Since it is also written in the reverse direction, one can decipher it in the following way: Не лик, но сокровения твои (Not the face, but your desires). By means of mirroring this technique the translator preserved the foreign-like form of the inscription - to Russian readers the sentence may sound as Old Church Slavonic. Nevertheless, Spivak deprived the sentence of the initial structure I show (odbijam in the Polish translation) that makes it harder to comprehend. All in all, it becomes obvious that both translators reflected the original strategies employed by J.K. Rowling only partially due to the limitations of the target languages as well as due to their personal decisions.

As the formal limitations of the paper do not allow to analyse more examples, it might be appropriate to enlist a few additional ones. The following fall into the three abovementioned categories: 
Alastor "Mad-Eye" Moody-Alastor "Szalonooki” Moody-Аластор "Шизоглаз" Хмури (anthroponym)

Gilderoy Lockhart - Gilderoy Lockart - Сверкароль Чаруальд (anthroponym)

Buckbeak - Hardodziob - Конькур (zoonym)

Fawkes - Fawkes - Янгус (zoonym)

the Deathly Hallows - Insygnia Śmierci - Дары Смерти (chrematonym)

Pensieve - myślodsiewnia - дубльдум (chrematonym - in both translations the translators transformed the original proper name into a common noun).

\section{Conclusion}

All things considered, the theoretical assumptions made in the paper are in fact confirmed in the analysis of the relation between the original conglomerates "the proper name-descriptions of the signified" and their equivalents in Polish and Russian. It is an inherent property of literary proper names to carry a complex load of linguistic and extralinguistic information that, in turn, triggers various connotations. Their discursive nature implies dependence on not only language and culture, but also on one's personality. Thus, even if the English, Polish and Russian languages and cultures were perfectly identical, the proper names would still be interpreted from the personal perspective of each translator and reader. Interestingly enough, Newmark suggests that "the translator should explain the connotations in a glossary and leave the names intact" ${ }^{43}$ what Polkowski did, yet with an insufficient degree of consistency. This proves that the Polish translator was actually conscious of the importance of the information instilled in the proper names by J.K. Rowling. Nonetheless, the variety of connotations stipulated by proper names and descriptions of their signifieds can be called as "the tip of the iceberg", since they constitute a portion of the totality of mental images of the elements of the literary world. To conclude, literature can be interpreted as designed to be shaped by discursive spaces of its receivers. The only feasible way of determining actual intentions of the writer is consulting particular interpretations of the text with him or her directly.

43 Newmark, Approaches, 71. 


\section{Bibliography}

About the Books: transcript of J.K. Rowling's live interview on Scholastic.com. Access 02.05.2017. http://www.accio-quote.org/articles/2000/1000-scholastic-chat.htm.

Алефиренко, Николай Ф. „Имплицитность художественного слова как когнитивнодискурсивная категория". Научные ведомости Белгородского государственного университета. Серия: Гуманитарные науки 10 (2011),12: 5-11.

BBC. Harry Potter and Me. Access 02.05.2017. http://www.accio-quote.org/articles/2002/1102-aebiography.htm.

Bertills, Yvonne. Beyond Identification. Proper names in children's literature. Åbo: Åbo Akademi University Press, 2003.

Cieślikowa, Aleksandra. „Jak ,ocalić w tłumaczeniu” nazwy własne”, in: Między oryginatem a przekładem, t. II: Przekład, jego tworzenie się $i$ wptyw (1996): 311-320.

Gibka, Martyna. „Hooch, Filch i Puszek, czyli jak polskie tłumaczenie Harry’ego Pottera wpływa na funkcję humorystyczną nazw własnych postaci”. In: Emocje w językach i kulturach świata, eds. E. Komorowska, A. Szlachta. Szczecin: Volumina.pl Daniel Krzanowski, 2016.

Gibka, Martyna. "Hooch, Filch and Fluffy: How the polish translation of Harry Potter influences the humorous function of the characters' names”. In: Komunikacja międzykulturowa $w$ świetle współczesnej translatologii. Literatura, eds. E. Kujawska-Lis, I. Ndiaye. Olsztyn: UWM w Olsztynie, 2014.

Kronzek, Allan Z., Elizabeth Kronzek. Ksiega wiedzy czarodziejskiej. Przewodnik po zaczarowanym świecie Harry'ego Pottera. Poznań: Dom Wydawniczy Rebis, 2008.

Kudlik, Małgorzata. "Переводческие практики в передаче смысловых имен собственных в польском и русском переводах книги Дж.К. Ролинг Гарри Поттер и философский камень”. In: Wschód-Zachód. Dialog kultur, ed. Z. Nowożenowa. Słupsk: Wydawnictwo Naukowe Akademii Pomorskiej, 2006.

Levy, Jiri. „Przekład jako proces podejmowania decyzji”. In: Współczesne teorie przekładu. Antologia, eds. P. Bukowski, M. Heydel. Kraków: Znak, 2009.

Lydon, Christopher. Access 02.05.2017. http://www.accio-quote.org/articles/1999/1099-connectiontransc2.htm. "The Connection (J.K. Rowling's interview)". Access 02.05.2017. http://www.accio-quote.org/articles/1999/1099-connectiontransc2.htm.

Małek, Magdalena. „O tłumaczeniach książki Harry Potter and the Deathly Hallows autorstwa J.K. Rowling”. In: Debiuty Naukowe II. Terminologia - translatoryka - terminografia, ed. M. Łukasik. Warszawa: Katedra Języków Specjalistycznych - Koło Naukowe BAJT, 2008.

Newmark, Paul. Approaches to Translation. Oxford: Pergamon, 1981.

Rowling, Joanne K. Harry Potter and the Philosopher's Stone. London: Bloomsbury, 2004.

Rowling, Joanne K. Harry Potter i Kamień Filozoficzny. Poznań: Media Rodzina, 2000.

Роулинг, Джоанн К. Гарри Поттер и Философский камень. Москва: Махаон, 2017.

Rutkowski, Mariusz. Nazwy własne w strukturze metafory i metonimii. Proces deonimizacji. Olsztyn: Wydawnictwo UWM, 2007.

Thomasson, Amie L. Fiction and Metaphysics. Cambridge: Cambridge UP, 1999. 
Venuti, Lawrence. The Translator's Invisibility: A History of Translation. London \& New York: Routledge, 1995.

Тынянов, Юрий Н. Поэтика. История литературьл. Москва: Кино, 1977.

\begin{abstract}
In the paper the author investigates the specificity of literary proper names and its implications on their translation. He focuses on the discursive process of projecting the descriptions of the elements of the literary setting onto their respective names. The main postulate is that literary proper names, apart from triggering various linguistic and extralinguistic connotations, primarily form a complex image of their signifieds in the minds of the readers in cooperation with the literary text itself. Accordingly, in the face of this cognitive potential that literary proper names have, the translator is forced to retain only its key aspects. This process of decision-making is grounded in knowledge, perception and the view of the world of each individual. The aforementioned assumptions are verified by means of comparing the way in which proper names and descriptions of their bearers function in the original text of the Harry Potter series with its Polish and Russian translations. Ultimately, the analysis leads to a conclusion that the process of translating literary proper names boils down not only to linguistic and cultural differences, but also to the personality of the translator and his or her conscious decisions.
\end{abstract}

Keywords: literary proper names, literary translation, discursive activity, the process of decision-making

\title{
SPECYFIKA LITERACKICH NAZW WŁASNYCH: HARRY POTTER W TŁUMACZENIU NA JEZZYK POLSKI I ROSYJSKI
}

\begin{abstract}
Abstrakt
W artykule autor analizuje specyfikę literackich nazw własnych i jej wpływ na ich tłumaczenie. Skupia się na dyskursywnym procesie projektowania opisów elementów literackiego świata przedstawionego na ich nazwy. Kluczowym postulatem autora jest stwierdzenie, że literackie nazwy własne, oprócz wywoływania różnych konotacji językowych i pozajęzykowych, tworzą przede wszystkim złożony obraz ich desygnatów w umysłach czytelników we współpracy z samym tekstem dzieła literackiego. W związku z tym, w obliczu takiego kognitywnego potencjału literackich nazw własnych, tłumacz jest zmuszony do zrekonstruowania tylko jego kluczowych aspektów. Niniejszy proces podejmowania decyzji osadzony jest jednak na jego światopoglądzie, wiedzy i percepcji rzeczywistości. Powyższe założenia
\end{abstract}


są weryfikowane poprzez porównanie sposobu, w jaki nazwy własne i opisy ich desygnatów funkcjonują w tekście oryginalnym sagi o Harrym Potterze z ich polskim i rosyjskim tłumaczeniem. Przeprowadzona analiza prowadzi do wniosku, zgodnie z którym na proces tłumaczenia literackich nazw własnych wpływają nie tylko różnice pomiędzy językami i kulturami, lecz również osobowość tłumacza i podjęte przez niego decyzje.

Słowa kluczowe: literackie nazwy własne, ontologia świata przedstawionego, tłumaczenie literackie, działalność dyskursywna, proces podejmowania decyzji 